\title{
八代工場回収ボイラ最適燃焼制御システムについて
}

\author{
十條製紙秝八代工場 塩 越 陽 平
}

\section{Optimum Combustion Control System for Recovery Boiler}

\author{
Youhei Shiokoshi \\ Yatsushiro Mill, Jujo Paper Co., Ltd.
}

Recovery boiler is a part of kraft pulp process. Untill now, it has been difficult to keep stable combustion in a recovery boiler.

We have developed optimum combustion control system useing meny new techniques. This system aimed at improvement of combustion stability, boiler efficiency and smelt reduction efficiency which were successfully established in our mill. In this paper, the summary of the system being introduced.

Keywords: Recovery boiler, Computer control, Combustion control, Optimum control.

\section{1.はじめに}

KP 設備の一部門である回収ボイラは, チッブ蒸解 工程より排出される黒液を燃焼し, 蒸解薬剤の回収及 び蒸気を発生させるボイラである。この種のボイラで は然焼が不安定になりやすいなどのため燃焼維持, 蒋 品回収率のアップなどに従来は多くのオペレータの手 が必要であった。また石油ショックによるエネルギー 費の高腾などもあり, 近年回収ボイラへの省エネルギ
一, 省力化, 省資源などのニーズが高まり, それらの 対応として，少数オペレータによる然焼の安定化，高 薬品回収率の維持, 蒸気出力の最大化, 低公害化など, ボイラハード設計を含めたより一厤きめ細やかな制御 システムが必要となってきた。筆者らは回収ボイラの 浐適化制御システムを開発，実用化し好結果を得てい るのでこのシステムの概要及び稼動結果を報告する。 写真 1 は当システムを導入したパワープラント中央操 作室の全景である。尚, 本稿は 1986 年 10 月，第 10

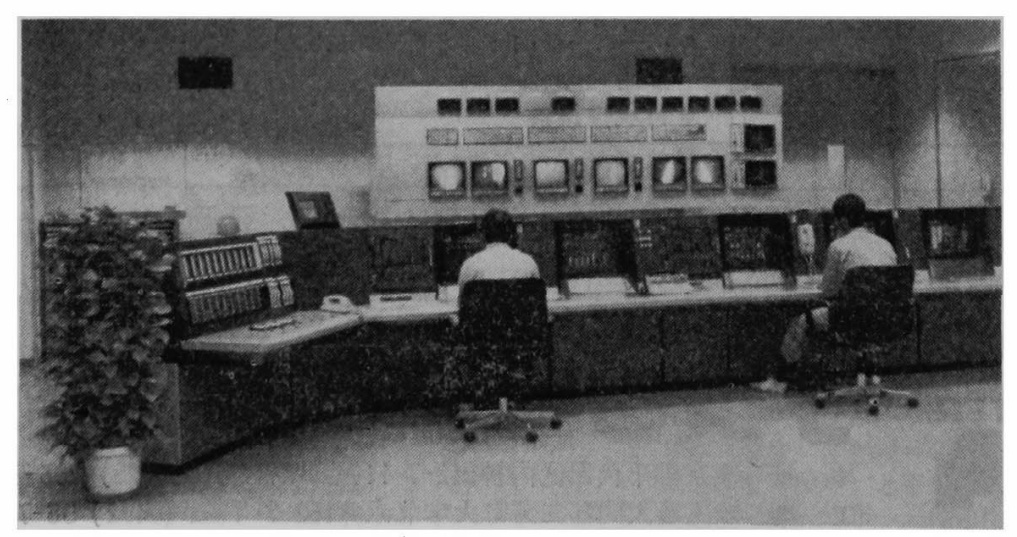

写真 1 パワープラント中央操作室全景 
回紙ハルプ計装技術発表会で講演した内容に加筆した あのである。

\section{2. パワープラントの設備概要}

当工場は新聞用紙, 上質紙, 書籍用紙などを年間約 27 万 $\mathrm{t}$ 生産している。これらのエネルギーセンター として新回収ボイラを含め常用 3 缶 2 機に再編成した。 パワープラントのエネルギー設備系統図を図1k，今 回最適制御システムを導入した川崎重工 KJ-4200 S ボ イラ諸元を表1に示す。

\section{3. 最適燃焼制御を前提とした高効本 ボイラの特徵}

表 1 に示すような高温・高压蒸気を発生する本ボイ ラの概略フローを図 2 に，最適化制御システムとボイ ラハードとの関係を図3に示す。ボイラは計算機制御 を行らに当り，八ード面からも多くの新技術の導入を 含めた改良が行われ，計算機に上る然焼制御の効果を より大きなるのにした。その中で特に制御の安定化に 菊与したシステムに次のものが上げられる。

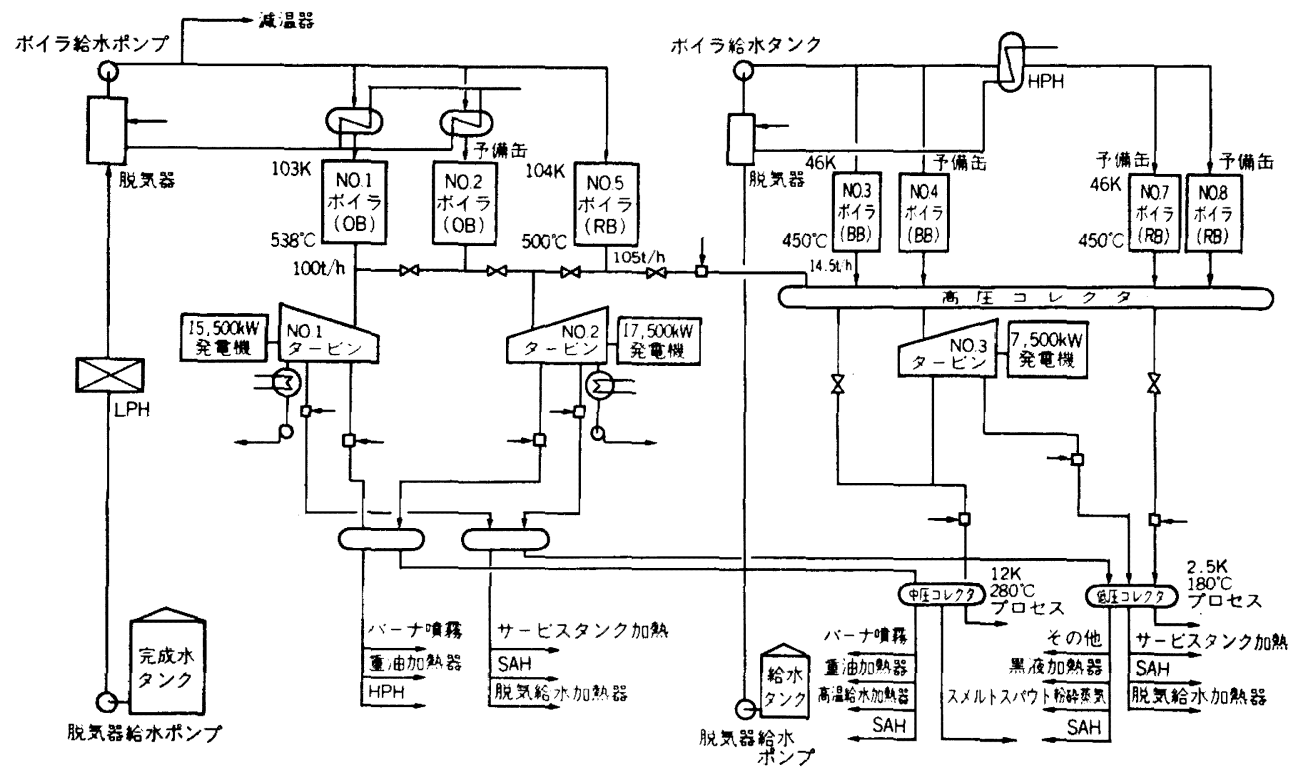

図1 八代工場エネルギ系統図

表.1 川崳 $\mathrm{KJ}-4200 \mathrm{~S}$ 形諸元

\begin{tabular}{|c|c|}
\hline 式 & 川崘 $\mathrm{KJ}-4200 \mathrm{~S}$ 形 ボイラ \\
\hline 黒液固形分処理量 & $700 t / d$ \\
\hline 黒 液 濃 度 & $70 \%$ \\
\hline 過熱器出口蒸気圧力 & $104 \mathrm{~kg} / \mathrm{cm}^{2}$ \\
\hline 過熱器出口蒸気温度 & $500^{\circ} \mathrm{C}$ \\
\hline 節炭器入口給水温度 & $135^{\circ} \mathrm{C}$ \\
\hline 量 & $105 \mathrm{t} / \mathrm{h}$ \\
\hline 燃 焼 方 式 & 黒液専焼 \\
\hline
\end{tabular}




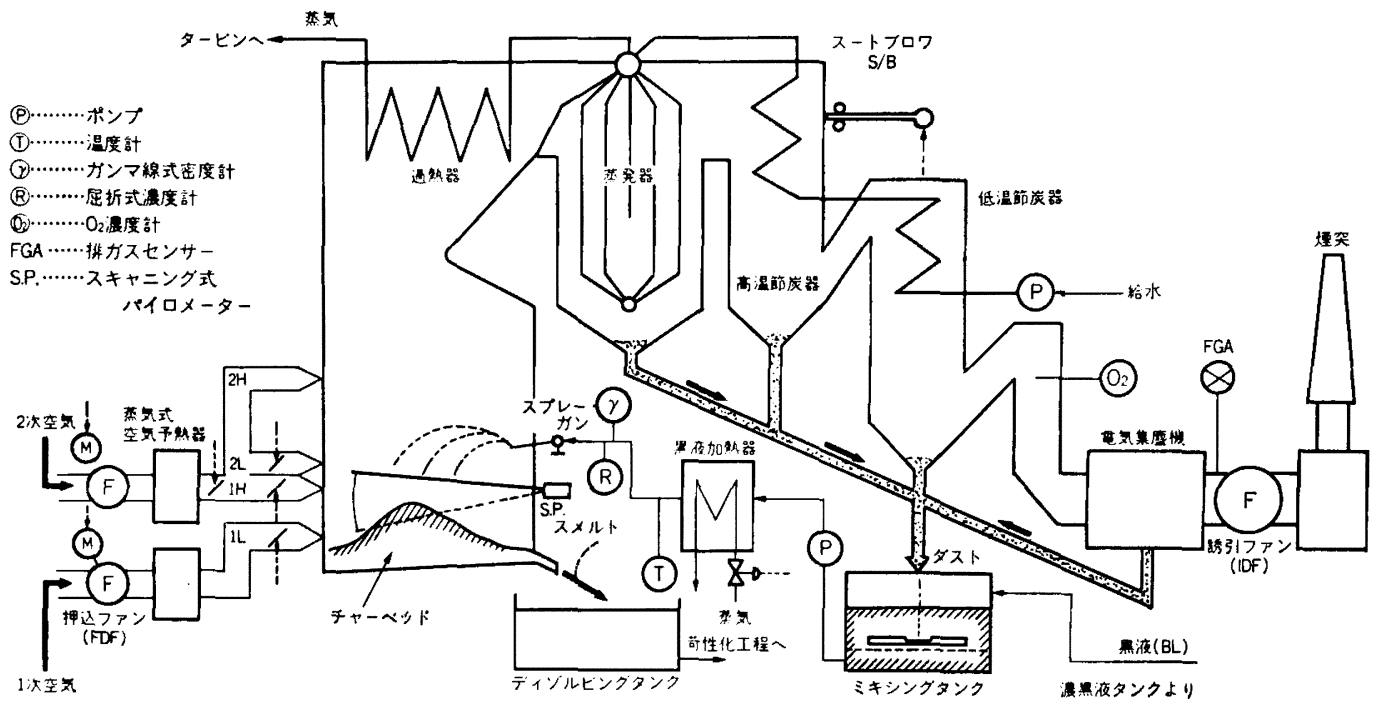

图 2 回収ボイラプラント概略フロー図

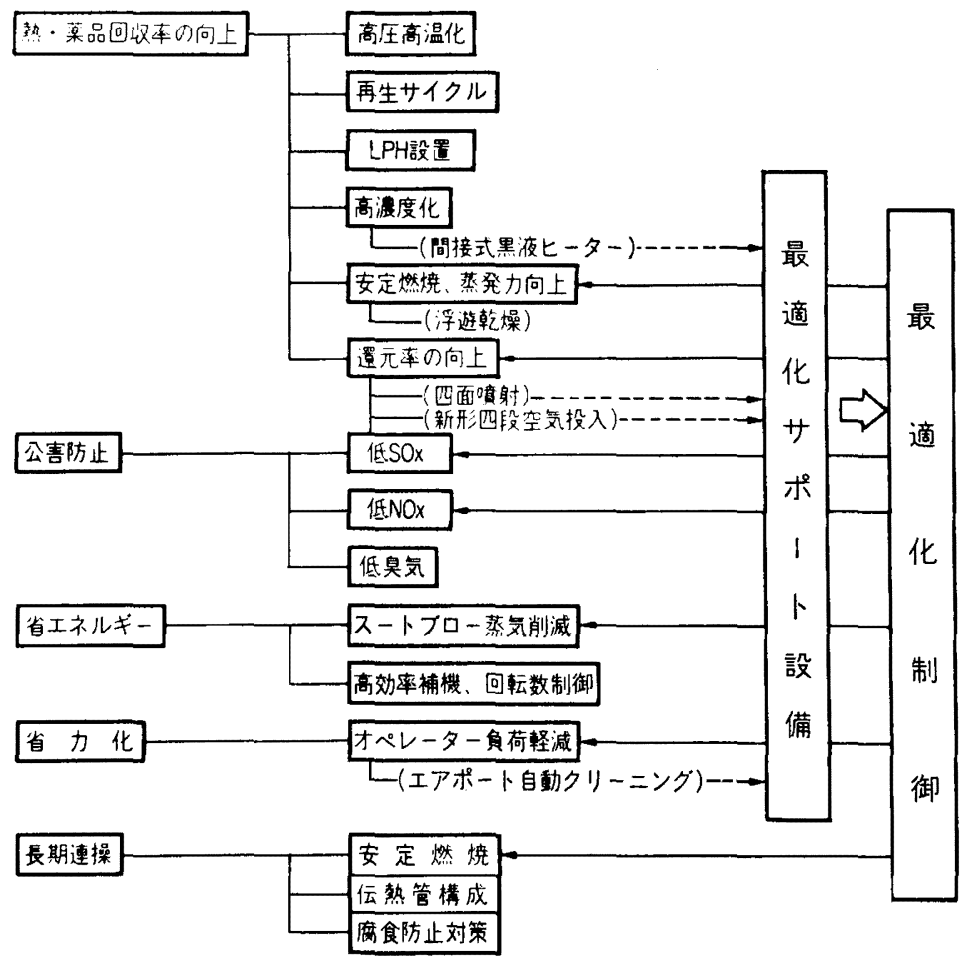

图 3 垠適制御システムとボイラハードとの関係図 


\section{1）間接式黒液ヒーター}

ドロップサイズ制御で，黒液温度变化により粘度を 変化させ，噴射黒夜の液滴サイズを変化させる目的で 使用するが，従来の直接式ヒータと異なり，加温用蒸 気と黑夜が直接接触しないため, 制御による温度变化 に伴なう，黑液加温用蒸気のドレン混入による黑液竖 度変化などが無くなり, 黑液ヒータでの大きな外乱要 因の一つが除去され，安定したドロップサイズ制御が 可能となった。写真 2 がその全影である。

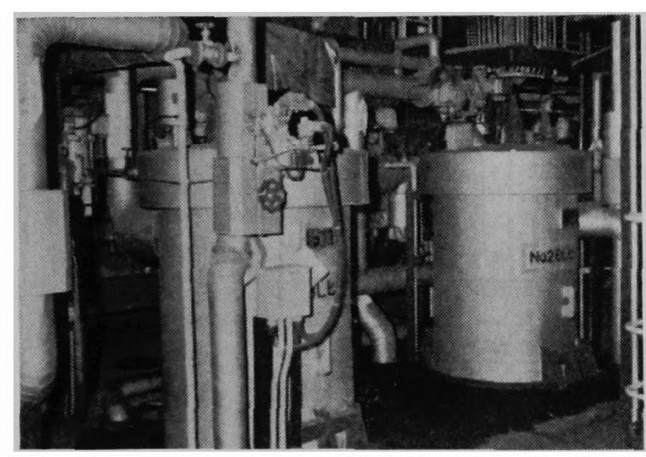

写真 2 間接式黒液ヒーター全景

\section{2）エアポート自動クリニーング装惪}

この装置は跈来から数時間ごとに, 人力で実施して いた，空気投入口に附着するスメルト及びダストの除 去作業を自動化したものである。今回は污れの度合が 早い一次低エフポートに設置した。

省力効果に加えてチャーベッドの形状が安定した。 これはダスト污れにより，エアポートごとの風压のア ンバランスを発生し，チャーベッド形状变動の主因と なっていたが，自動化し一定周期で，人力時より早い クリニーンク周期としたので，エアポート形状が常時 一定となり，風圧のフンパランスが製くなったための 効果である。写真3に缶前側の設政状態を示した。

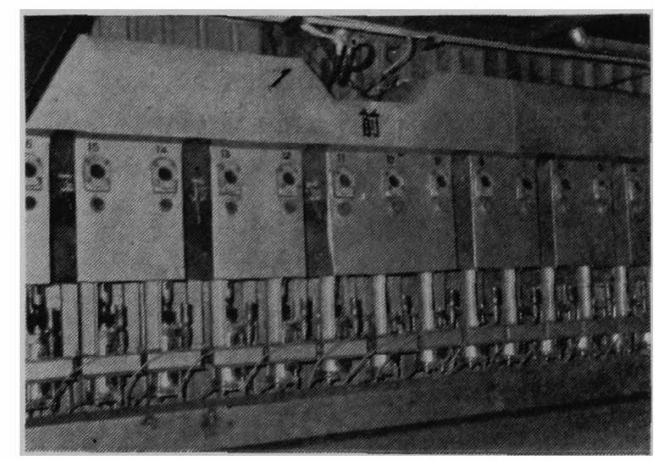

写真 3 缶前側のエアポート自動クリニーング装置

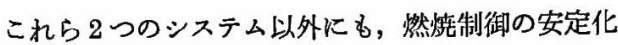
につながった新型 4 段空気投入方式, チャーベッド形 状安定に寄与した黒液 4 面噴射方式, 省エネルギーに つながった FDF，IDF 他のインパータ制御化などが 上け゚られる。いずれも最適燃焼制御システムの機能を フルに発揮させるための有用な設備となっている。

\section{4. 最適燃焼制御計算機システム構成}

本システムは, パワープラントの VDT (ビシュア ル・ディスプレー・ターミナル）設備の一部分で構成 しており，最適然烍制御用之しては演算周期の高速性 が要求される然焼制御，及びマイナーループ制御につ いては, 分散形 DDC である TOSDIC-SS に, その 他の最適化制御及び電力デマンド制御, 日報処理デー 夕収集解析機能，及びメンテナンス機能を上位計算機 である TOSBAC7/40E に機能分担している。図4 K 計算機システム構成図を示した。

\section{5. 最適燃焼制御システムとセンサー}

最適然焼制御システム構築上, 従来から設置されて いたセンサーの他に次に挙るセンサー及び新たに開発 した演算処理方法によって運転状態の監視が充分に出 来るようになった。

1) 排ガスセンサー（FGA）

然焼排ガス中の成分として $\mathrm{CO}, \mathrm{CO}_{2}, \mathrm{SO}_{2}$ 濃度を制 御用データ (後述) として電気集塵機 $(\mathrm{E} / \mathrm{P})$ 出口でオ ンライン測定し, $\mathrm{CO}$ 濃度は $\mathrm{O}_{2}$ 濃度と共に低過剩空 気燃焼制御用に, $\mathrm{CO}_{2}$ 擞度は燃烧状熊の監視に用いら れている。测定器は, $\mathrm{CO}, \mathrm{CO}_{2}$ オパシティーは $\mathrm{ECO}$ $\mathrm{NICS7700を,} \mathrm{SO}_{2}$ は SYCONEX-5000を使用した。 これらの他に, 環境監視用 $\mathrm{SO}_{2}$ 計として场場 $\mathrm{S} 100$ 形 (サンプリンク゚方式）を使用した。

\section{2）ガンマ線式密度計及び届折式㳻度計}

これらのセンサーは, 貲射黑夜の成分濃度を知る目 的で従来から使用されている。ガンマー線密度計は照 液の無機成分に, 屈折式濃度計は黒液の有機成分に感 度が高いといわれている。雨センサー共, 通常はメン テナンスフリーの機器である。今回は従来より使用さ れている両測定データに喷射黑液温度を考虑する事に より，唭射黒夜の有機成分濃度を推定する方法を開発 し，これを外乱の把握及び補梢制御に用い，従来困難 とされていた有機成分浱度をぺースとした運伝指標を 用いる事が可能となり，本制御システムの基本制御デ 一タの一角となった。ガンマー線式密度計は YOKOGAWA 8800 を, 風折式滥度計は LSC 社 Model-829 Nを使用した。 


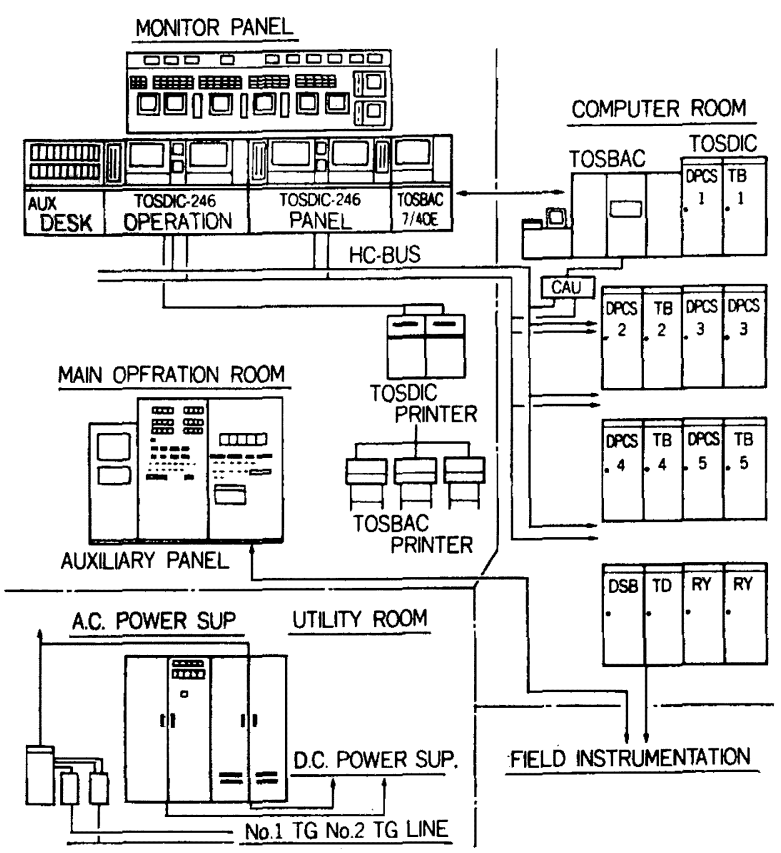

図 4 計算機システム模成龱

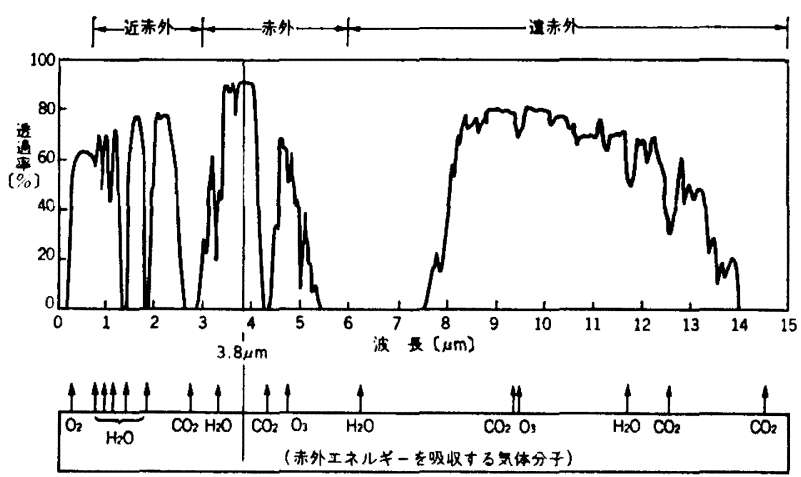

図 5 光の大気透過率

3）スキャンニングパイロメーター（放射温度計） 従来から驴内チャーベッドの温度及び高さの監視制 御の目的のために，多くのパイロメーターが使用され ている。その多くは測定波長に $0.5 \mu \mathrm{m}$ 近傍より 0.9 $\mu \mathrm{m}$ 近傍の近赤外領域を使用している。しかし近赤外 領域の下方では，ガス体温度にも感度が高いので师内 チャーベッドレベル及び表面温度を測定する際には， 炬内燃燒ガス体温度とチャーベッド表面温度との差が 小さく，正確なチャーベッド表面温度及びチャーベッ ドレペルの測定が出来なかった。そこで今回のシステ
ムは，哣内ガス体の影整を極力少なくするために，测 定波長に赤外領域の $3.8 \mu \mathrm{m}$ ，半值幅 $140 \mathrm{~nm}$ を使用 し，スキャン角度 $50^{\circ}$ ，スキャンスピード $5 \sim 50 \mathrm{rps}$ のパイロメータを陚作し良好な結果を得た。また従来 複数個のスポット式パイロメータによりディジル的 チャーベッドレベル測定しか行党ず，情報量も少なか ったが，フナログ的測定が可能となり情報量も上がっ た。但しチャーベッド温度は测定出来てすガス体温度 が測れないため，チャーベッド直上ガス温度を湘定す る場合には，0.5 $\mu \mathrm{m}$ 波長域測定のパイロメータが必要 


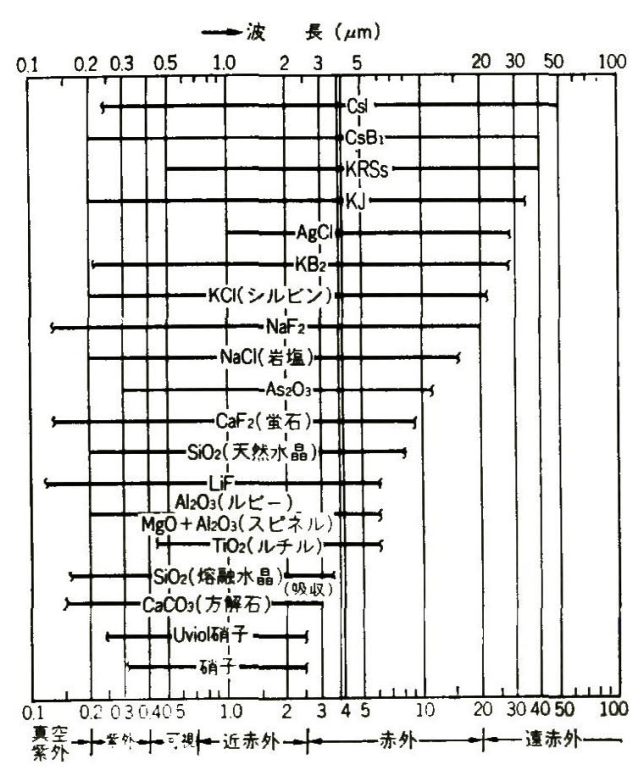

図 6 光学材料の光透過率

である。現システムではスラグスクリーン直下， S/H 入口に燃焼ガス温度湘定用温度計（K素子）を取付て いる。図5に光の大気透過率グラフを示した。測定波 長が赤外域の $3.8 \mu \mathrm{m}$ であるため, 光学系材料として 一般的ガラスや石英ガラスなどは使えず $\mathrm{CaF}_{2}$ (䖝石) により構成した（図6参照)。しかし $\mathrm{CaF}_{2}$ の材料特 性として急熱・急冷に弱いことから炬内・外遮断用フ イルターには命却用パージ空気取入口構造などを含め, のぞき穴の設計を綿密に行う必要がある。また本シス

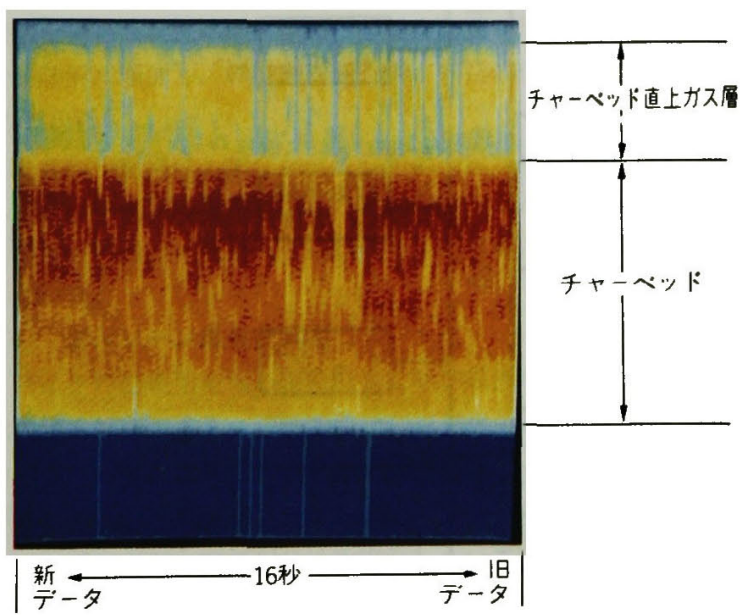

写真 4 画像処理後のスキ+ンパイロメータのテータ
テムでは測定位置が师底から約 $2500 \mathrm{~mm}$ の所にある が，スメルト・ダストによるエアポート污れを除去し， 正常なチャーベッドレベル測定状態を維持するために は, エアポート自動クリニーング装置を取付けた方が 良い。本システムではスキャンニングパイロメータよ り数点の情報を取出しているが，パイロメーター信号 を画像処理する事で，より多くの情報が入手出来る。 写真 4 はスキャンパイロメータでチャーベッド温度を 計测した信号に画像処理を施こしたもので，チャーベ ッドレペルが明確に判別出来る。写真 5, 写真 6 は S/H 最下部に取付けられているスートブロー蒸気に より, チャーペッド及びチャーベッド直上然焼ガス温

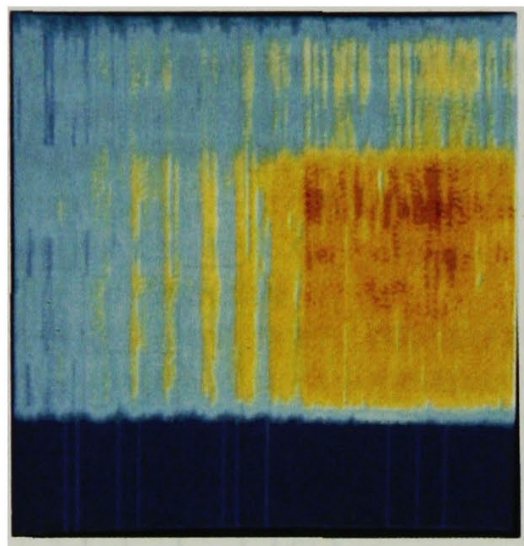

写真 5 スートブローによりチャーベッド が冷されていく過程

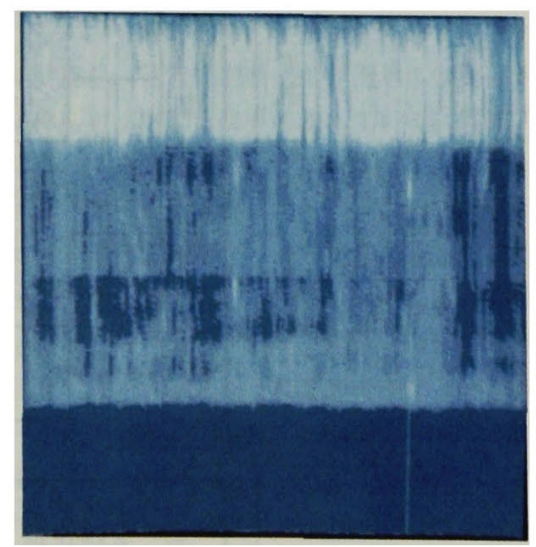

写真 6 スートブロー終了直後の冷された チャーベッド 
度が下げられていく過程をとらえた写真である。これ らの写真からわかるように画像処理をする事で，才ぺ レーターが判読しやすい情報となり，よりきめ細かな 操業に寄与するものと考光られる。パイロメーターは 的チノー製 IR-E 改造型である。

\section{6. 最適燃焼制御システム機能梓成及び概要}

本システムは演算周期の高速性要求などから上位下 位計算機により制御を分担している（図７）。

\section{1) 焱焼制御}

目的は過鄱空気の低減であり，今回開発した黑液有 機成分流量によって基本的 2 次総空気流量を決め， ᄀ イードフォワード制御を行っている。また， $\mathrm{CO} ， \mathrm{O}_{2}$ 濃度により燃狫状態に応したフィードシック補正を行 っている。また，スートブローなどでの一次的な回流 芒硝量の增加による然焼不安定対策として，1 次低空 気流量を一時的に增加させる芒硝補償制御などがある。 黑液有機成分流量による発熱量管理は有機成分濃度推
定式の開発により確立されたもので，有機成分濃度推 定式は約 200 サンプルの黒液のオフライン分析データ を統計処理して確立したもので，図8に推定式を用い て黒液有機成分濃度を推定し，それから求めた有機成 分流量と主蒸気流量との実機データの相関図を示した。 有機成分浱度が精度良く求められている事がわかる。

2）ドロップサイズ制卸(チャーベッドレベル制御) 賀射黑液の適正な浮遊乾燥状態の維持を目的として, 黑液の情報を基本とし炬内状況，排ガス情報より補正 を加える制御である。補正項目としては噴射黒液圧力,

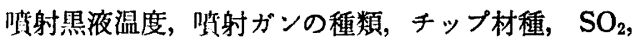
空気流量などがある。また，チャーベッドレベル制御 ではチャーペッドレベルが適正範囲に入るように，パ イロメータの測定信号変化により黑液温度を变化させ, 黑夜の粘度を変化させる事で液滴サイズを変化させる。 これにより黒液の落下時間が変化し，乾燥度合及び浮 遊然焼時間が変化し，結果的にチャーペッドを上下さ せる制御である。また，極端に山の高さが高低した場

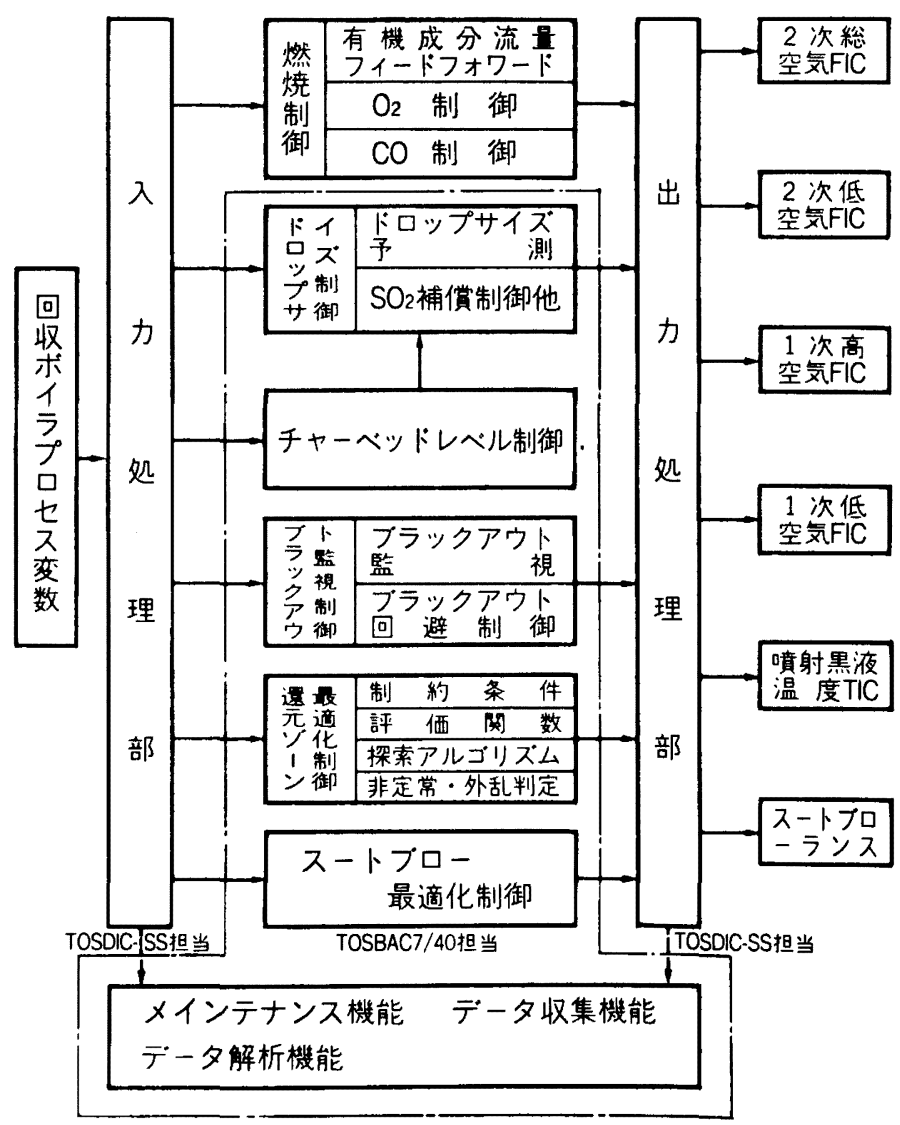

図 7 最適燃焼システム機能满成四 


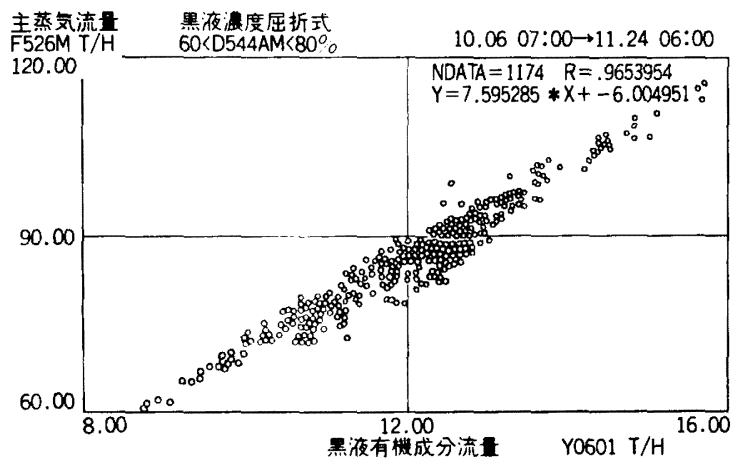

図 8 主蒸気流量と黑液有機成分流量相互困

合には，一次低及びチャーベッド頂上部空気流量の增 隇を併用し，すばやく適正範囲内に㞍せるようになっ ている。

\section{3）ブラックアウトの監視と制街}

黒液の高源度化及びボイラ本体の性能向上によって, 従来のような極端なブラックアウトは発生しなくなっ た。しかし，低過剩空気然焼制御を志向するシステム では，チャーベッド全体にたえず十分な然焼用空気を 行きわたらせ，均一な然焼る行わせることが必要であ る。

このため，局部的な空気不足による燃焼不良などに ついて監視が必要であり，本システムでは蒸発力， 燃焼温度，排ガス分析，黑夜性状などに関連した 18 項目のブラックアウト監視用変数を用意した。変数は それぞれ絶対值の高低, 変化率, 長期的变化傾向の 4 つの属性を持たせ, 各变数の属性の AND・OR の組 み合わせにより監視を行っている。回避制御では然焼 状態を商正な状況に䒝すため，各段空気及び黑液温度 を一時的に增加し，然焼状態回復後，回澼動作前の状 況に戻す。

これらの制御は，オペレータの経験的な知識を移植 しパターン化して登録したもので，オペレータによる ロシックの追加・変更・登録が簡単に出来るようにな っている。

\section{4）迤元ソーン取道化制御}

ボイラの燃焼用空気の各段投入比率を最適な配分状 態にする制御である。評価関数は蒸気発生效率，遝元 効率の双方を考虑したボイラ効率，チャーベッド温度， 排ガス分析值の非線形結合式を用い，1 次低空気是と チャーペッド值上空気配分比を操作している。また回 収ボイラの場合は操作量と評価関数との間の再現性に 難があるため，制御のモデル化はむずかしく実用性に そしかった。このため本システムでは試行探索法によ
り最適化制御を行った。探索アルゴリズムは既存の手 法を改良した簡略シンプレックス法を使用している。 また，本システムでは規定値以上に早い変化率で変化 する外乱での影暗仙いては除外して評価を進め，規 定値以下の遅い变化率での変化についてのみ制御動作 するように設計されている。この考え方はボイラの長 期安定燃焼維持に大きく寄与した。

\section{5）スートブロー最適化制御}

妒内のダスト污れの効率的除去と，回流芒硝增加に よる然焼への外乱補償など，オペレータの経験を芳恚 に入れたシーケンシャルスートブロー，そしてコンピ ニータの常時監視による状態量変化データにより起動 するグループスートブローとの組み合わせにより，ス 一トブロー蒸気量の省エネルギーを目ざした制御であ る。またボイラーの操業期間が長くなるにつれて，ス ートブローパターンが変化するが，2種類のスートブ ロー万式を組合わせた事によりオペレータの監視が容 易になった。またオペレータがシーケンス変更などを 考慮する際のフォローとして，スートブロートレンド 画面などを使用し，迅速に判断ができ簡単に制御パタ ーン及び条件変更が出来るようになっている。写真 写真 8 ，写真 9 に画面を示す。

(1) シーケンススートブロー

オペレータの経験及びデータ解析の結果などに基 つき， 1 工程最大 64 ステップのスートブロ一順序 を設定出来る。各ステップ間ごとの休止時間長もお の招の任意に設定出来る。またグループスートブロ 一がシーケンススートブローに割込むかたちで運転 されるが，グループスートブローの割込が終った後， 設定された時間中はグループスートブローイングさ れたランス NOをスキップしながらシーケンススー トブローを行う。

(2) グループスートブロー 


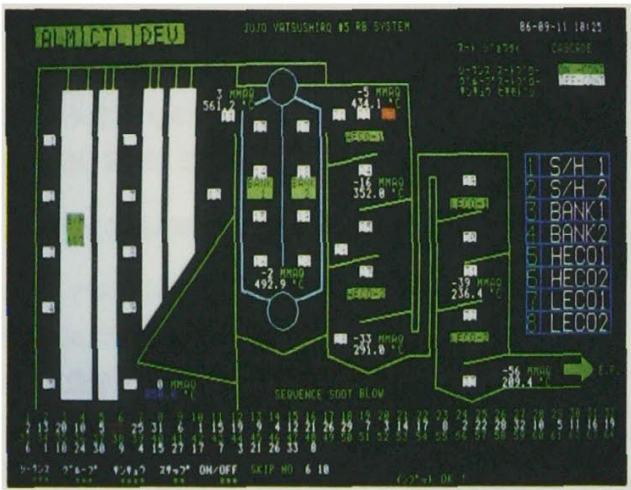

写真 7 スートプロー制御画面

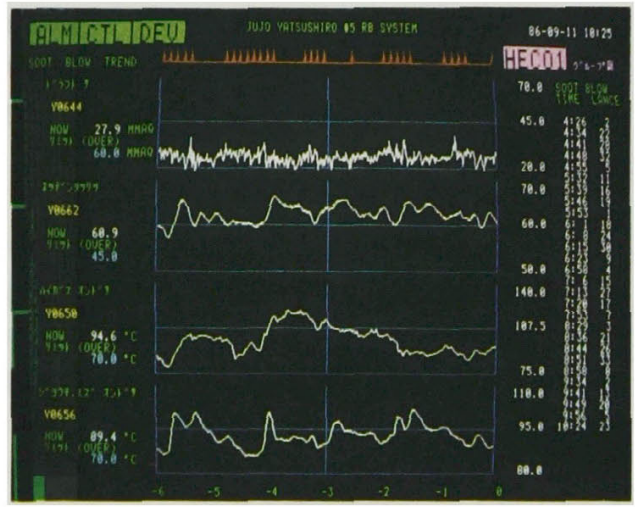

写真 8 スートブロートレンド画面

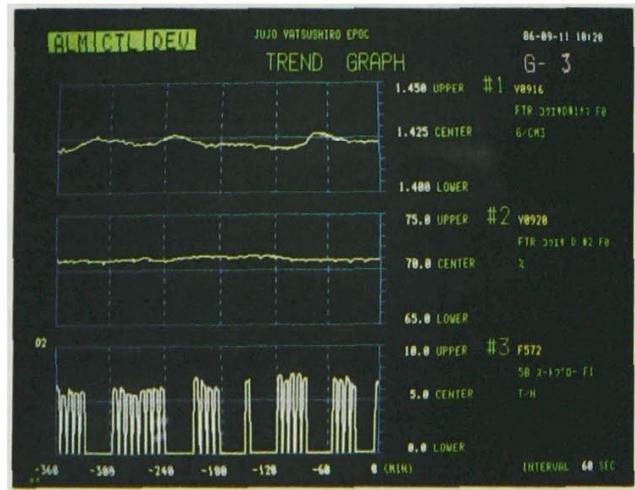

写真 9 トレンドプロット画面
ポイラ本体及びェコーを含め全体を 8 グループに 分割し，各グループごとに燃焼排気ガスドラフト差 王, 燃焼排ガス温度差, 蒸気及び水の温度差, 熱伝 達率, 主蒸気温度, ク゚ループスートプロ一起動時間 間隔(但しグループスートブローの時のみ), など 6 項目をコンピュータにて常時監視し, 設定値を越 えると各グループ単位でスートプローが行われる。 また，各グループ最大 10 ステップのブローイング パターンを作れる。また，ドラフト差圧，排ガス温 度差，主蒸気温度などで起動した場合は，ブローイ ンク゚中に監視データーが正常に戻った時点で，スー トプローを中止して起動されていたダループスート ブローを終了する。その他ブラックアウト時に S/H 部ランスをスキップするなど数種類の制御条件を用 意している。

\section{6）データ収集・解析及びメインテナンス機能}

最適制御システムとは，メーカー及び計装担当者を 含めた初期ファインチューニング終了後も, 蒸解黑液 性状の変化や，その他操業状況の変化に伴なら制御方 法の変更や，制御を使い込むほどに向上するオペレー タの操業ノウハウを含めた，より高度なファインチュ 一ニングの実施などが行われるであろら性質のもので ある。このため本システムでは制御アルゴリズムの才 ペレータへの公開及び教育を含め, 一般的にあまり大 規模でない変更やファインチューニングについては後 述の機能を使用し，いらいらメーカの手をわずらわせ なくてもオペレータの手で調査し，メインテナンス機 能を使用する事により容易に変更出来るように設計さ れている。このほか外部でデータ解析をする場合など の対応として，8インチフロッピーディスクへのデー タパック機能も用意してある。以下扰もなデータ解析 機能について列記する。

○データ収集箐囲

今回 CRT 制御システムにタグナンパー登録をし ているすぺての入出力に対して，データ集収が可能 である。通常はオンラインにより次の様な仕様でデ 一タを取込める（ここでは上位計算機担当分のみ記 载したう。

○ヒストリカルデータ解析

同時に 114 点集収，1 点あたり最大 2048 データ プロット可能

データプロット条件

- 最適燃焼制御が安定定常状態のみ集収，20点

・還元ソンーン制御が定常状態のみ集収，22点

- 指定周期集収, 72点

データ解析機能 
- 自己相関・相互相関・主成分分析

- 2 変数相関プロット処理

○ヒストリカルデータパック機能

8インチフロッピーディスクに IBM フォーマ

ットにより 256 点パック，1265 データ/点

○トレンドグラフ

最大 30 点, オートフレームコピー可能

○トレンドデータログ

最大 32 点データをプリントアウト

○日報処理データ

各プラントごとにプリントアウト

以上，最遒燃燒制御システムの概略を述ぺてきたが， 制御画面についてもオペレータの監視操作がやりやす いように作らなければならない。制御画面の代表的な ものを写真 7 から写真 11 に示した。

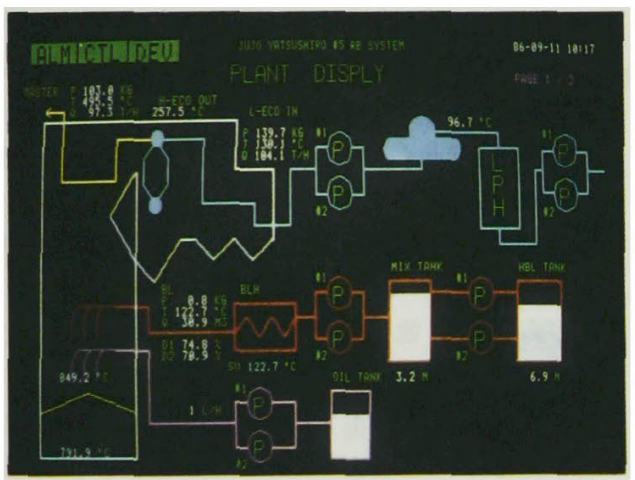

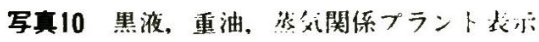

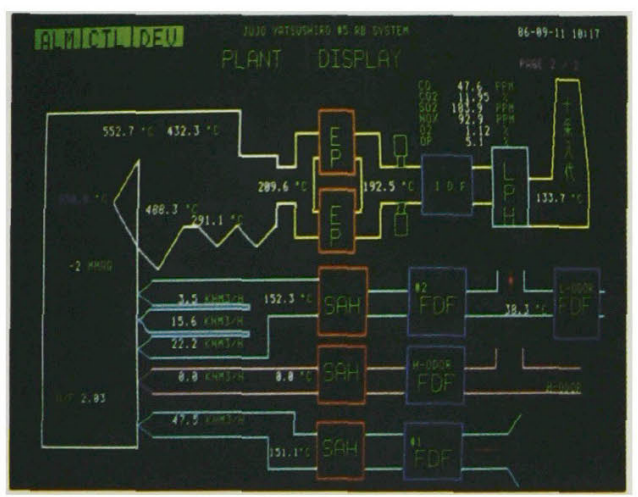

写真11燃焼空気・排ガス関係プラント表示

\section{7. 最適燃焼制御システム導入による効果}

本システムは 1984 年末に完成し, 連続運転に入っ た。その後ボイラ本体の一部改良に伴なら調整を含め, 1985 年末にすべての調整が終了し現在に至っている。 この間以下の様な効果が確認されている。

(1) 操業の安定

計算機制御を前提としたボイラ本体の設計及び計 算機によるきめ細かな運転制御を行ら事により，高 効㸉で安定な燃焼を維持する事が出来た。

(2) 省エネルギー

エコー出口の $\mathrm{O}_{2}$ 濃度で $3.5 \%$ 前後の過鄱空気率 から $1.2 \% \pm 0.4 \%$ 程度の低過剩空気率燃焼を確立, スートブローの頻度を 90 本/日から 70 本/日に削減, $\mathrm{O}_{2}$ 低然焼による燃焼空気の減少に伴ないスチーム エアヒータの蒸気量の削減，IDF，FDF のインハ 一タ化による電気量削減など省エネルギー金額は全 体で年間約 1 億円に達した。

(3) 薬阂回収

常に 96〜97\% の高スメルト還元率の維持に寄与。

(4) 公害防止

平均 $\mathrm{SO}_{2}$ 值は手動操業の約半分, $\mathrm{NOx}$ 值 $2 / 3$ に隇少した。

(5) 省力化

燃焼状態の監視制御の自動化，スートブローの自 動化, 黑液性状変化の追従なと゚の効果により，大幅 にオペレータの負荷を軽減する事が出来た。また直 接最適制御とは関連しないが, CRT オペレーショ ンにあたり，オペレータにとっての最適なオペレー ション設備のありかたとして，今まで多数輌築され たシステムを見ると，CRT オペレーション＝ボー ドレスオペレーションといら考えか? 何もかにも CRTに扎し込み，オペレータがアラーム処理やぺ ージ替に追われている設備や，その逆に多くのパネ ル計器 (指示計他) をハードで CRT 附近に設置し, オペレータがすばやく目的の計器を探すことが出来 ず，ビニールテープなどで目印を付けて操業してい る設備などが見らけられる。どちらの場合むプラン トの異常時など緊急を要する場合，CRT オペレー タへの作業のさまたけ゚となり，察急処㯰におくれを 生じる可能性がある。

当システムではこれらの点に注目し；CRT とパ ネル計器との最適な棲み分けによる使いやすい設備 を目ざし，人間工学的見地からの検討も含め十分な 検討を加えた。その結果としてオペレータの CRT による確認頻度が特に高く，重要な指示値はディジ 
タル表示器で常時表示とした。またこの表示器は才 ペレータがまちがわずに，一目で探せる数しか設置 しないといら考えで，当システムは最大 12 個（現 状 10 個）に制限した。アナンシェータも重要度別 に3ランクに分け，更に最重要ランクはハードで表 示した。このことによりオペレータの監視作業に広 がりがでた。写真1の CRT 前方のディジタル表示 器が設置されているパネルが本システムで検討した 結果にもとづき設置したパネルである。また省力化 により小人数のオペレーションが可能になるが（当 システムは 6 人で操業), 反面 CRT オペレータと現 場パトロール貝の連絡が覀くなりがちである。この ため同時無線通話装直などを操業管理者，CRT 監 視オペレータ，現場パトロール要員に常時捲帯させ， 常に操業状態についての情報交換，作業報告，作業 指示などを全員で受けられるよらにする事により， 異常発生時の処理などが後手にならずに済む。また CRT オペレータの操業中の孤独感や責任の重压感 などからくる心細さや不安感などの精神的負荷など が軽隇され，オペレータのより信頼性のオペレーシ ヨンが可能となった。

\section{8. あとがき}

現在では省エネルギー効果のみを取り上げると，円 高ドル安, 重油単価值下げなど, システム導入当時と は大幅な環境の変化があったが，全体的視野から見る と現時点でも大幅な投資効果があったものと確信して いる。特に回収ボイラに対する技術的な面について述 べると，従来まではただ薬品が回収出来れば良い，蒸
気が出れば良いなどの域で操業されて招り，技術デー タ的にはあまりアプローチされていなかったが，今回 データ集収，オペレータノウハウに対するデータ解析 による解明など多くの技術向上につながる技術蓄積が 出来た。特にオペレータの操業方法の変化の一つとし て，アナログ的，定性的操業感覚だったのが，ディジ タル的, 定量的操業感覚に变化し, これによる操業レ ベルの向上には著しいものがあった。今後より最適な センサー及び制御アルゴリズムの開発により，より最 適な制御が可能となる事を期待する。本システムは当 社と陎東芝殿, 川崎重工陎殿との 3 社共同開発により 完成されたものである。またスキャンニングパイロメ 一タの開発については战チノー殿に多大な御協力を得 た。その他このシステムを完成させるために御協力下 さった関係各位に深く感謝すると共に敬意を表する次 第である。

\section{考支献}

1）黑崎，井床，他：回収ボイラ最適化制御システム の開発，川崎重工技報 第94号（1986.12）

2）松田：回収ボイラの現状技術と将来の展望，紙パ 技協誌 40(6) (1986)

3）塩越，熊木：紙パ動力設㣁に括ける最近の計装制 御技術, 計装 28(7) (1985)

4）饭塚，村松，他：紙パルプ工業プロセスの最適化 制御システム，東芝レピュー 41(10)（1986）

5）飯塚，他：回収ボイラおよび連続蒸解釜の最適化 紙パルブ技術タイムス 29(9)（1986） 